\title{
ENVIRONMENTAL PROTECTION VERSUS INCENTIVES FOR FDI INFLOWS: ABATEMENT TECHNOLOGIES MATTER
}

\author{
YOUNG-HAN KIM, EUN MO YANG
}

\begin{abstract}
:
This paper examines how environmental regulation affects the FDI strategies of parent firms in developing countries (the South) and developed countries (the North) when there are differences in the emission abatement technology between these countries. More lenient environmental regulations of developing countries are likely to attract more foreign capital inflows with higher risks for being pollution haven. As long as the emission abatement technology of the multinational corporations is superior to that of the South, lenient environment regulation to induce foreign capital inflows turns out to be the optimal policy. Also when social concerns about pollution are higher than the critical value, there is a tougher environmental regulation. Moreover, the welfare of developing country is maximized with the foreign capital inflows as joint-venture, suggesting higher incentive policies for joint-ventures with higher abatement technology.

We also demonstrate that stricter environmental regulation is applied if the foreign firm invests as a monopoly firm instead of joint-venture. The larger market size of the developing economy also induces stricter regulation.
\end{abstract}

\section{Keywords:}

FDI strategy; Emission standard; R\&D; Developing country; Environmental regulation

JEL Classification: F18, F23, Q56

\section{Authors:}

YOUNG-HAN KIM, Sungkyunkwan University, South Korea, Email: kimyh@skku.edu EUN MO YANG, Sungkyunkwan University, South Korea, Email: superqn@skku.edu

\section{Citation:}

YOUNG-HAN KIM, EUN MO YANG (2015). Environmental Protection versus Incentives for FDI Inflows: Abatement Technologies Matter. International Journal of Economic Sciences, Vol. IV(1), pp. 25-44., 10.20472/ES.2015.4.1.002

The many valuable inputs and comments from IISES conference in Malta, 2014 and SKKU Econ Seminar participants are deeply appreciated. This work was supported by the National Research Foundation of Korea Grant funded by the Korean Government (NRF-2012S1A5A2A01015910). 


\section{Introduction}

While economic asymmetry between developed and developing countries is increasing continuously, Foreign Direct Investment (FDI) has served as a major path for the capital formation of developing countries. As shown in figure 1 and diverse recent studies, FDI is a major source of capital formation, especially in leastdeveloped countries (LDCs). FDI is obviously not only a supporter of their capital formation but also provides technology and management knowledge. Additional investments are created and high quality technology with their know-how is transferred by FDI (Kristine (2013)). It is particularly important for LDCs to develop advanced technology via FDI.

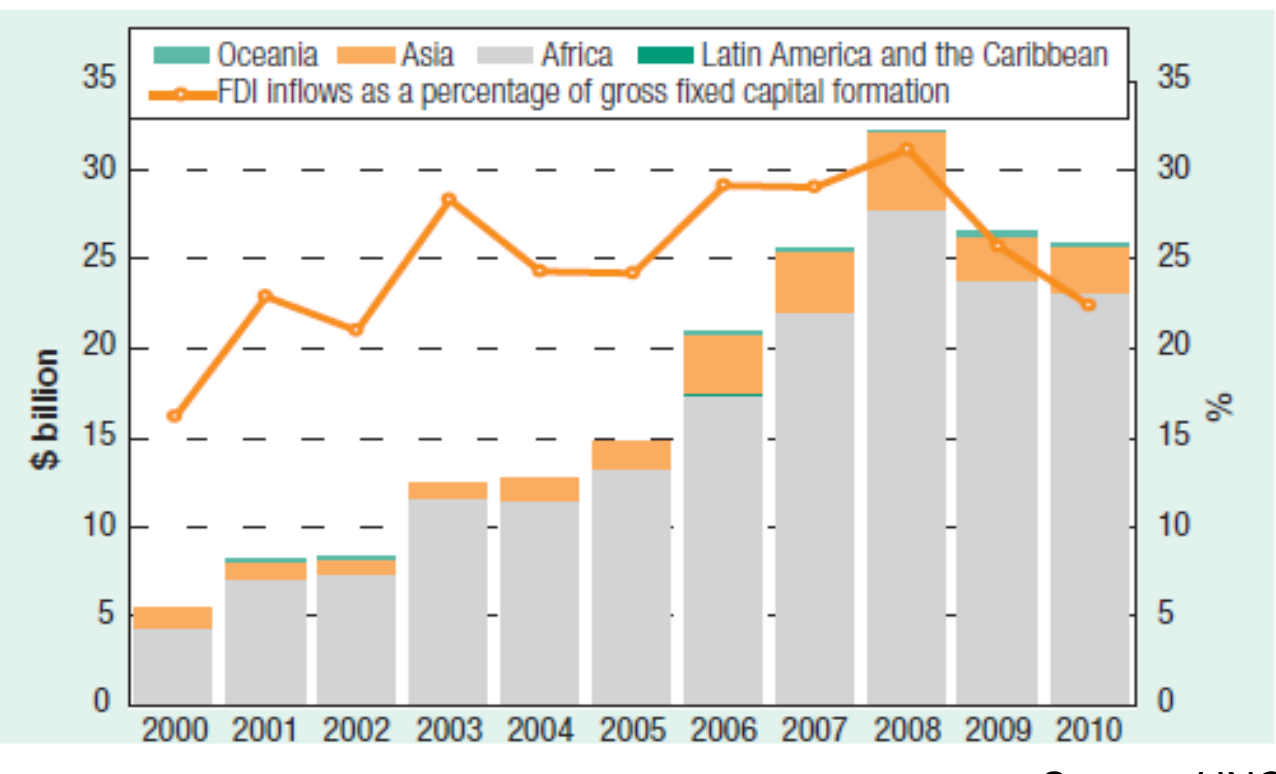

Source: UNCTAD(2011)

[Figure 1] FDI inflows, 2000-2010

However, the environmental issues involved with FDI attract global attention due to wide spread debate on the exports of polluting industries to less developed economies via FDI. If a government adopts lenient environmental policies, the country may become a pollution haven due to higher incentives for polluting industries to be migrated to the lenient policy areas. If a stricter environmental regulation is applied, the incentives for FDI inflows with higher abatement technologies are reduced. Therefore, developing countries face a policy dilemma between enhanced competitiveness with higher FDI inflows via lenient regulation and environmental protection.

This paper examines optimal environmental policies to resolve the policy dilemma between lenient environmental policies to induce FDI inflows and environmental protection of developing economies. Based on a simple model 
assuming asymmetric environmental technologies and regulations between developed and developing economies, we demonstrate that when the emission technology of the developing economy is higher than the critical level, the market dominated by a single joint-venture is the unique equilibrium. We show that if the social concerns about pollution is less sensitive than the critical level, the developing economy provide lenient regulation to induce joint-venture even when the emission of the joint-venture is increased. However, the developing economy takes a tougher regulation when the social concerns and sensitivity about the environmental pollution is higher than the critical level, and the market size of the developing is larger. This paper also demonstrates that the environmental regulation gets stricter when the foreign firm dominates the developing market as a monopoly firm instead of jointventure after the exit of the inefficient domestic firm.

It is true that emission abatement technologies in developed countries are better than those in developing countries. As European Commission Joint Research Centre \& PBL Netherlands Environmental Assessment Agency (2012), although all developing countries has increased their emissions on average by $6 \%, \mathrm{CO}_{2}$ emission from China has increased by $9 \%$ and those from India has increased by $6 \%$ in 2011 . Those increases from China and India have significantly responsibility of the largest increase in global emission of 1.0 billion tones in 2011 . There are many reasons for this, but it is primarily due to international differences in emission abatement technologies between developed and developing countries.

Due to the low level of the abatement technology in developing countries, the governments of those countries cannot choose strict regulation. If a government adopts strict regulations, national firms will have lower competitiveness. If a government adopts more lenient regulations, this can minimize the disadvantage for national firms but local pollution could become a serious threat.

The Clean Development Mechanism (CDM) is aimed at reduction greenhouse gas emission and supporting sustainable development in the host countries (Christoph (2007)). The countries that have responsibility for emission reduction under the Kyoto Protocol (i.e. developed countries) must invest their technology and money in countries without emissions targets (i.e. developing countries). This helps the developed countries to meet their emission reduction targets by allowing them to purchase CERs (certified emission reductions) through CDM projects. Therefore, given increasing concerns about emission pollutions, developed countries have more incentives to invest in developing countries. From this point of view, it is necessary to consider what the optimal strategy of developing countries should be.

Therefore, it is certain that a certain proper emission regulation is one of the main factors which effect on FDI location decisions. The proper emission standards can be a solution that leads to investment in developing countries by developed countries. The most important contribution from FDI is that ESTs (environmentally sound technologies) are transferred from the developed countries to the developing countries. Thus developing nations may be able to reduce their emissions through 
the advanced abatement technology provided by the developed country. The government of the developing country can thereby not only raise their competitiveness in the international market but also maintain a clean environment.

There are many methods of environmental regulation but in this paper, only emission standard setting is considered. Although there are diverse international environmental policies, emission standard is getting popular recently and the previous paper (Abe and Zhao (2005)) also pointed out the necessity of considering location decisions under emission standard model. Thus, in this paper, the model focuses on emission pollution, for which emission standards are the maximum permitted emission level fixed by government for environmental protection. For example, pollution producers pay an emission tax for their total emissions. However, in emission standardization, the government permits emissions up to the emission standard level. Then, only the amount over the standard level is under regulation and the pollution producer needs to pay for exceeding the standard. Therefore, a high emission standard means lenient environmental regulation while a low emission standard means strict environmental regulation. In Korea, there has been emission taxation since $1^{\text {st }}$ September, 1983. The emission taxation consists of 'basic taxation' and 'excess taxation'. It is necessary to pay both the basic tax and the excess tax for sulfur oxides and dust. However, for other pollutants a firm only needs to pay the excess tax depending on the degree to which they exceed the emission standard (Kim and Whang (2010)).

There are several papers that have studied FDI between two countries which have different environmental policies. Rauscher $(1995,1997)$ examine FDI location using an expanding international capital movement model. This work observed the location decision of a monopoly between $\mathrm{N}$ numbers of countries that each has differential environmental policies. In addition, Barrett (1994) and Kennedy (1994) explored the environmental regulation strategy of governments and the effect on firm FDI location decisions. Barrett (1994) considered the differences between Cournot and Bertrand competitions. In addition, transboundary pollution was considered by Kennedy (1994). Ulph and Valentini (1997) analyzed location choices between international oligopoly markets. This paper derived location decision strategy under consideration of the relations between upstream-firms and downstream-firms, which means inter-sectoral linkages.

However, Abe and Zhao (2005) examined not only firm location choice but also endogenous international joint ventures (IJV). Therefore, Abe and Zhao (2005) has differences with previous studies. The authors considered that optimal emission tax depends on the emission abatement technology of the developing countries involved. They point out that IJVs are formed when there are optimal emission taxes. They also postulated that deregulation of the minimum share increases the welfare of the developing countries under a JV. It is a noteworthy that this study ignored the fact that the technology of parent firms can be improved over time. In their model, abatement technologies were given at the outset and then never changed, although the total emission amount was changed by the level of technology. Developing 
countries also only concentrated on forming FDI or IJV by implementing an attractive environmental policy in the model of Abe and Zhao (2005).

This study highlights the fact that there are emission standard levels as a tool of environmental regulation in both developing and developed countries. For simplicity, the model of this paper focuses on the environmental technology industry and abatement technology. These are the most different points compared with previous studies.

This paper examines how environmental regulation affects the FDI strategies of parent firms in developing and developed countries when there are between-country differences in abatement technology. In addition, the paper considers the optimal emission standard for each case, assuming that an emission standard is an effective way to solve the regulation dilemma for developed countries. However, the core focus is on determining what level of emission standard is optimal under various situations, dependent on formation of JV or FDI in the developing country. In addition, the optimal welfare of the developing country based on the social concerns about environmental pollution is considered through analysis of findings.

The rest of the paper is organized as follows: Section two introduces the basic model of emission standards and FDI strategy. Section three presents the threat point whereat bargaining breaks down. Section four describes the endogenous choices between the formation of the international JV and full-ownership FDI. Section five analyzes the optimal emission standard for the South under the fullownership FDI and IJV. Concluding remarks and summaries are then given in Section six.

\section{The basic model}

We examine the case where there are two countries, a developed country (the North) and a developing country (the South). Both countries have their own environmental regulations. Each country has a representative firm, firm $\mathrm{N}$ in the North and firm $S$ in the South, and they compete over homogeneous products. All firms emit pollutants as they produce outputs, while firm N's emission level of pollutants per unit of outputs is lower than that of firm $S$ due to higher emission abatement technologies. All outputs are assumed to be consumed in a third country to focus on government regulation policies with respect to pollutant producers.

The game is structured as follows. In the first stage, the South government determines her emission standard level to maximize their welfare, given the North's emission standard level. In stage two, the firm $\mathrm{N}$ decides whether to invest in the South or stay in the North after observing country S's environmental policy. If the firm $\mathrm{N}$ decide to move in the South, two representative firms $\mathrm{N}$ and $\mathrm{S}$ decide whether to form a JV or not. Two firms bargain to form an international JV and they bargain over location, outputs, and shares of the JV. If bargaining succeeds, both firms begin the production as a JV. If bargaining breaks down, both firms produce their goods 
separately.

\section{(given the North)}

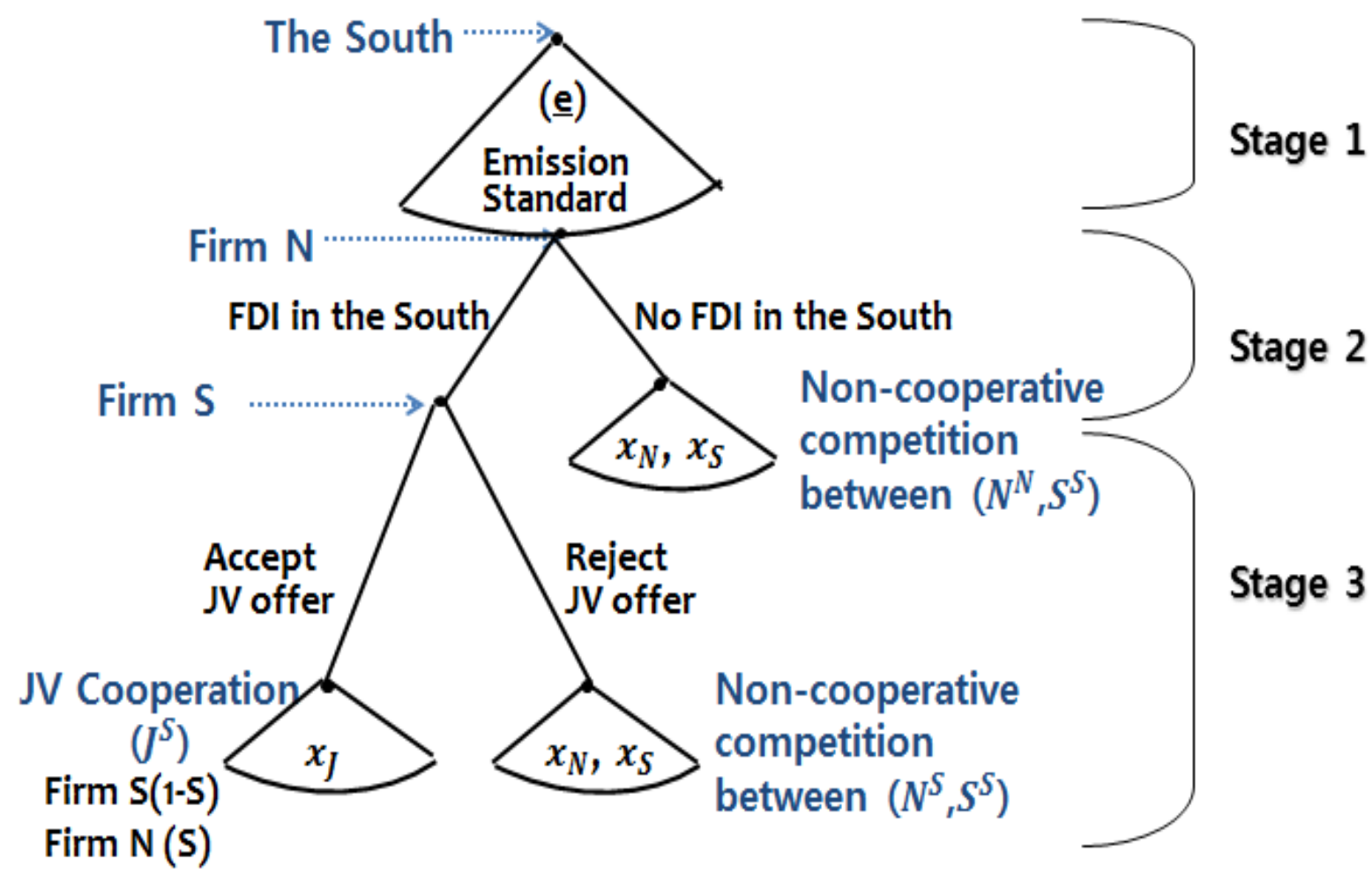

[Figure 2] Three-stage game tree

There are three possible scenarios vis-à-vis the location and the type of firm: (i) each firm chooses to produce independently in their home countries, (ii) both firms are located in the South but choose to produce independently, or (iii) both firms produce together as $\mathrm{JV}$ in the South.

To examine the model over time, the two stage game model is solved using backwards induction: the second stage of the game is analyzed first, in which bargaining is either successful or unsuccessful. Then the first stage, in which the South determines their emission standard level, is investigated.

\section{The threat point}

There is the threat point where both firms produce their goods independently in either country. If bargaining for setting up joint venture between firm $\mathrm{N}$ and $\mathrm{S}$ breaks down, both firms produce goods independently and they choose to locate in either 
country. At the threat point, both firms compete as either a domestic Cournot or an international Cournot as Celik and Orbay(2011): (i) an International Cournot is Case 1, wherein each firm produces in their home country independently, and (ii) a Domestic Cournot is Case 2, wherein both firms are located in the South but choose to produce independently.

The emission tax structure, considering location, and abatement technologies, has an effect on the output levels of each firms. If both firms have incentive to produce positive outputs, it is a duopoly. If one firm produces positive output while the other produces zero output, it is a monopoly.

The profit function of the firm $j$ which is located in country $i$ can be formulated as:

$$
\prod_{j}\left(x_{N}, x_{S}, i\right)=p\left(x_{N}+x_{S}\right) x_{j}-w_{i} a x_{j}-\left(e_{j}-e_{i}\right) x_{j}
$$

where $w_{i}$ is the wage cost and $\underline{e_{i}}$ is the emission standard level per unit of output in country $i$. Also, $x_{j}$ is the output of firm $j$ and $a$ is unit labor requirement per unit of output of firm $j$. If $e_{j}$ is indicated as emission per unit of output of firm $j$, then it can be stated that $e_{N} \leq e_{S}$ because the abatement technology of firm $\mathrm{N}$ is more efficient than firm S. In addition, the inverse demand function is considered to be linear in this model:

$$
p\left(x_{N}+x_{S}\right)=\beta-\alpha\left(x_{N}+x_{S}\right), \beta>0, \alpha>0 .
$$

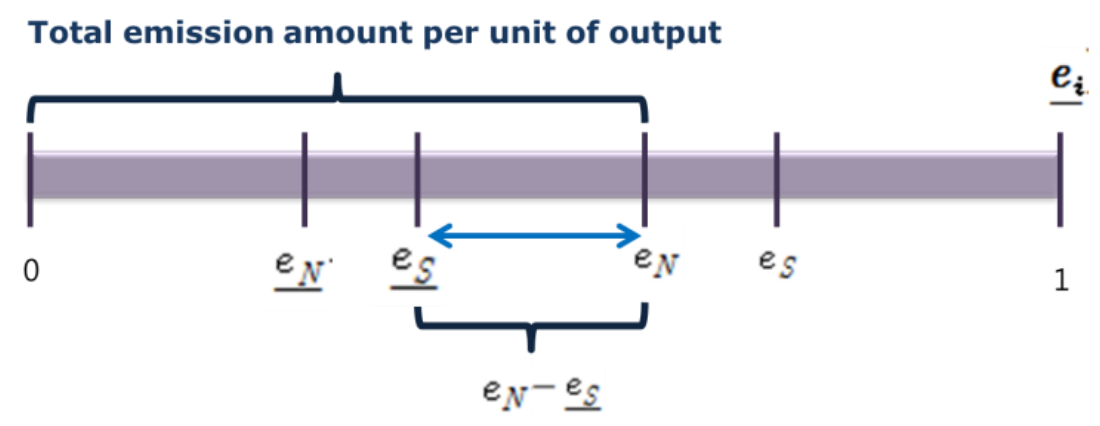

The amount over the standard limit per unit of output $=$ COST

[Figure 3] Level of per unit emission and emission standards of country $\mathrm{N}$ and $\mathrm{S}$

It is assumed that firms pay emission tax when their emissions are higher than the emission standard set by the government. For example, if firm $\mathrm{N}$ produces in the South, firm $N$ pays her per unit emission tax by $e_{N}-\underline{e_{S}}$, where $e_{N}$ is firm N's actual emission, and $\underline{e_{S}}$ is the emission standard set by the government $S$ as shown in figure 4. It is a de facto marginal cost for firm $\mathrm{N}$ to produce in the South. Therefore, a higher emission standard represents lenient regulation in this model.

We focus on the difference in environmental policies between two countries. Thus, 
for simplicity, wages are normalized to $w_{N}=w_{S}=0$, assuming $\underline{e_{S}}>\underline{e_{N}}$.

\subsection{International Cournot Competition: Case 1}

In this section, we consider Case 1, an international Cournot competition, in which firm $\mathrm{N}$ is located in the North and firm $\mathrm{S}$ is located in the South. The notable point here is that we assume $\underline{e_{S}}>\underline{e_{N}}$ because the South determines its emission standard level considering firm S's lower emission technology in comparison to firm $\mathrm{N}$. Firm $\mathrm{N}$ can choose to stay in its home country (the North) or to move to the South. If firm $\mathrm{N}$ stays in the North, firm $\mathrm{N}$ pays emission tax by emission standard of the North which is relatively strict. However, if firm $\mathrm{N}$ moves to the South, it can reduce the emission tax payment additionally since the more lenient emission standard is applied in the South, i.e., $\underline{e_{S}}>\underline{e_{N}}$. Therefore, firm $\mathrm{N}$ has a strong incentive to move to the South. To focus on the strategic aspects of government S's policies between the environmental issues and capital formation incentives, we assume that there is no moving cost involved in this model.

\subsection{Domestic Cournot Competition: Case 2}

In Case 2, the domestic Cournot competition, both firms are located in the South. We assume that $\underline{e_{S}}>\underline{e_{N}}$, which means the North has stricter environmental policies than the South. Thus firm $\mathrm{N}$ moves to the South which has more lenient emission regulations.

There is a cost difference of parent firm depending on firm location because of wage costs and emission standard levels. $\left(w_{N}-w_{S}\right) a+\left(\underline{e_{S}}-\underline{e_{N}}\right)$ is the cost difference when the firm is located in the North and the South. The marginal cost of firm $\mathrm{N}$ located in country $i$ is given as: $w_{i} a-e_{N}+\underline{e_{i}}$. However, since wage rates of each country were normalized to 0 , only the different emission standards of each country affects the location decision of the firm N. Thus, the South has an incentive to choose a more lenient emission standard compared to the North, so as to make both firms have an incentive to locate in the South.

Under a duopoly in the South condition, the profit maximization problems of firm $\mathrm{N}$ and $\mathrm{S}$ are formulated as Eq. (2a) and (2b), respectively.

$$
\begin{aligned}
& \pi_{N}\left(x_{N}, x_{S}, i\right)=p\left(x_{N}+x_{S}\right) x_{N}-\left(e_{N}-\underline{e_{S}}\right) x_{N} \\
& \pi_{S}\left(x_{N}, x_{S}, i\right)=p\left(x_{N}+x_{S}\right) x_{S}-\left(e_{S}-\underline{e_{S}}\right) x_{S}
\end{aligned}
$$

The outputs for case 2 are given in Eq. (3a) and (3b), from solving the first order 
conditions of Eq. (2a) and (2b) simultaneously:

$$
\begin{aligned}
& x_{N}^{c}=\frac{e_{S}+\beta-2 e_{N}+e_{S}}{3 \alpha} \\
& x_{S}^{c}=\frac{e_{S}+\beta+e_{N}-2 e_{S}}{3 \alpha}
\end{aligned}
$$

Thus, if Eq. (3a) and (3b) are combined with Eq. (2a) and (2b), the noncooperative payoffs for each firm from domestic Cournot competition are derived as (4a) and (4b). These non-cooperative payoffs serve as reservation payoffs or threat point payoffs in the bargaining process to set up joint ventures between two firms.

$$
\begin{aligned}
& \pi_{N}^{c}\left(\underline{e_{S}}, x_{N}, x_{S}\right)=\alpha\left(x_{N}^{c}\right)^{2} \\
& \quad=\frac{\left(\underline{e_{S}}+\beta-2 e_{N}+e_{S}\right)^{2}}{9 \alpha} \equiv \pi_{N}^{c}\left(\underline{e_{S}}, e_{S}\right) \\
& \pi_{S}^{c}\left(\underline{\left.e_{S}, x_{N}, x_{S}\right)=\alpha\left(x_{S}^{c}\right)^{2}}\right. \\
& \quad=\frac{\left(\underline{e_{S}}+\beta+e_{N}-2 e_{S}\right)^{2}}{9 \alpha} \equiv \pi_{N}^{c}\left(\underline{e_{S}}, e_{S}\right)
\end{aligned}
$$

We can observe from Eq.(3a) and (3b) the relationships outputs with emission standard levels or abatement technology.

$$
\begin{aligned}
& \frac{\mathrm{d} x_{N}^{c}}{\mathrm{~d} \underline{e_{S}}}>0, \quad \frac{\mathrm{d} x_{N}^{c}}{\mathrm{~d} e_{N}}<0, \quad \frac{\mathrm{d} x_{N}^{c}}{\mathrm{~d} e_{S}}>0 \\
& \frac{\mathrm{d} x_{S}^{c}}{\underline{\mathrm{d} e_{S}}}>0, \quad \frac{\mathrm{d} x_{S}^{c}}{\mathrm{~d} e_{N}}>0, \quad \frac{\mathrm{d} x_{S}^{c}}{\mathrm{~d} e_{S}}<0
\end{aligned}
$$

We can observe from Eq. (5a) and (5b) that the outputs of the two firms increase as the emission standard $\underline{e}_{S}$ increases. In other words, both firm $\mathrm{N}$ and $\mathrm{S}$ may have higher production in the South if the South government chooses lax environmental regulation. We can also observe that the output of firm $\mathrm{N}$ increases with higher $e_{S}$, whereas that of firm $\mathrm{S}$ decreases, implying that firm $\mathrm{N}$ produces more when firm S's abatement technology deteriorates and vice versa.

We assumed that $e_{S} \geq e_{N}$. Thus, $\pi_{N}^{c}\left(\underline{e_{S}}, x_{N}, x_{S}\right) \geq \pi_{S}^{c}\left(\underline{e_{S}}, x_{N}, x_{S}\right)$ for any $\underline{e_{S}}$. The emission standard $\underline{e_{0}}\left(e_{S}\right)$ is the level at which $x_{S}^{c}=0$ such as Eq. (6).

$\underline{e_{0}}\left(e_{S}\right) \equiv-\beta-e_{N}+2 e_{S}$

We define the threat point payoffs set as $\left(\pi_{N}^{0}, \pi_{S}^{0}\right)=\left(\pi_{N}^{c}, \pi_{S}^{c}\right)$. Also both firms exist in the market only with $\underline{e_{S}}>\underline{e_{0}}\left(e_{S}\right)$.

Lemma 1 (The threat point). Suppose that $e_{S} \geq e_{N}$ and $\underline{e_{S}}>\underline{e_{N}}$. At the threat point of the bargaining game, both firms produce a positive output in the South if 
$\underline{e_{S}}>\underline{e_{0}}\left(e_{S}\right)$

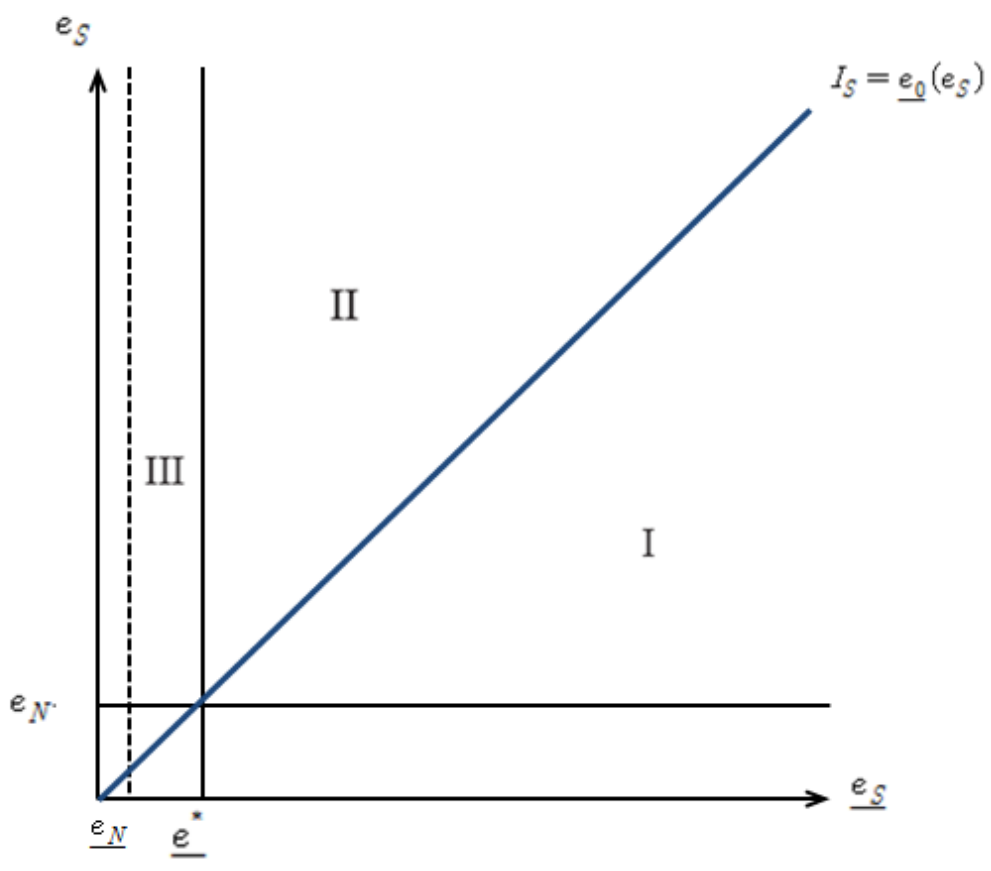

[Figure 4] Domestic Cournot

Case 2 in which both firms is located in the South and produce independently is illustrated in figure 4. As shown in figure 4, the emission per unit of output for firm $S$ $\left(e_{S}\right)$ increases as the South government determines looser environmental regulation, which means a high value of $\underline{e_{S}}$. Curve $I_{S}$ is $\underline{e_{0}}\left(e_{S}\right)$ as the prohibitive emission standard level at which firm $S$ has no further incentive to produce a positive output. Thus, firm $S$ exists in the market only if $\underline{e_{S}}>\underline{e_{0}}\left(e_{S}\right)$. In addition, $\underline{e^{*}}$ shows the prohibitive emission standard level at which even monopoly firm $\mathrm{N}$ becomes zero profit. This means that neither firm produces anything if $\underline{e_{S}}<\underline{e^{*}}$. Then, in area I, both firms produce a positive output at the Cournot equilibrium. In area II, firm S produces zero output and firm $\mathrm{N}$ only exists in the market as a monopoly. In area III, both firms produce nothing.

\section{The formation of an international JV : Case 3}

The payoffs from the non-cooperative Cournot competition serve as threat point payoffs or reservation payoffs in the bargaining process to set up joint venture between two firm $\mathrm{N}$ and $\mathrm{S}$. The equilibrium of the international joint venture is 
determined through the Nash bargaining process on the share of the joint venture (JV). When JV is formed, produce as a monopoly firm with the advanced abatement technology of firm $\mathrm{N}$ with no additional cost. Thus, the profit function of $\mathrm{JV}$ is formulated as Eq. (7) if the JV is located in the South.

$$
\begin{aligned}
\pi_{J} & =p\left(x_{J}\right) x_{J}-\left(e_{J}-\underline{e_{S}}\right) x_{J} \\
& =\left(p-e_{N}+\underline{e_{S}}\right) x_{J}
\end{aligned}
$$

In Eq. (7), $x_{J}$ is the output of the JV and $e_{J}$ is emission per unit of output of the JV. The noteworthy fact here is the assumption that the JV adopts the advanced technology of firm $\mathrm{N}$ without any extra cost.

When JV is formed, the decision on the output level is made as a monopoly firm, and therefore, the former output decisions by firm $\mathrm{N}$ and S, i.e., $x_{N}^{c}, x_{S}^{c}$, are merged to a monopoly decision, $x_{J}$. In addition, the emission abatement technology of firm $\mathrm{N}$ is adopted as the emission abatement technology of the joint venture such as $e_{J}=e_{N}$ as the emission per unit of output of the JV. The inverse demand function is considered to be linear: $p\left(x_{J}\right)=\beta-\alpha x_{J}, \beta>0, \alpha>0$.

Defining the share of firm $\mathrm{N}$ is $s$ and that of firm $\mathrm{S}$ is $1-\mathrm{s}$, where the $\mathrm{JV}$ is formed if $s \in(0,1)$. Then the profit functions of each firm are written as Eq. (8) if the JV is formed.

$\pi_{N}^{J}=s \pi_{J}, \pi_{S}^{J}=(1-s) \pi_{J}$

The decision on the share of joint venture is determined as the Nash bargaining solution as follows:

$V=\left(\pi_{N}^{J}-\pi_{N}^{0}\right)\left(\pi_{S}^{J}-\pi_{S}^{0}\right)$

In the Nash product, $\pi_{N}^{J}$ and $\pi_{S}^{J}$ are the payoffs from forming the JV. Similarly, $\pi_{N}^{0}$ and $\pi_{S}^{0}$ are the payoffs at threat point, i.e., the payoffs from non-cooperative competition between firm $\mathrm{N}$ and $\mathrm{S}$. The payoffs from the joint venture is higher than the those from the non-cooperative competition for both firm $N$ and $S, \pi_{N}^{J}>$ $\pi_{N}^{0}$ and $\pi_{S}^{J}>\pi_{S}^{0}$, since the monopoly profits from the joint-venture is always higher than the summed profits of firm $\mathrm{N}$ and $\mathrm{S}$ from non-cooperative competition with the advanced abatement technology of firm $\mathrm{N}$ adopted by the joint venture with no additional cost. The equilibrium share of the joint venture is derived from solving joint-welfare maximization problem with respect to the equilibrium share of the joint venture reflecting the bargaining powers of two firms, i.e., two firms' reservation payoffs from non-cooperative competition as follows:

$$
\frac{\partial \pi_{N}^{J}}{\partial x_{j}}=0
$$




$$
\frac{\partial V}{\partial s}=0: \pi_{N}^{J}-\pi_{N}^{0}=\pi_{S}^{J}-\pi_{S}^{0}
$$

The joint venture firm chooses the equilibrium output level that maximizes the monopoly profits and then divides the JV profits according to each firm's share, $s$ and $1-s$, that is determined from (10b). The equilibrium outputs and the profits of the joint venture are given as follows:

$$
\begin{aligned}
& x_{J}\left(\underline{e_{S}}\right)=\frac{e_{S}+\beta-e_{J}}{2 \alpha} \\
& \pi^{J}\left(\underline{e_{S}}\right)=\alpha\left(x_{N}^{M}\right)^{2}=\frac{\left(e_{S}+\beta-e_{J}\right)^{2}}{4 \alpha}
\end{aligned}
$$

The equilibrium joint venture profits are allocated to firm $\mathrm{N}$ and $\mathrm{S}$ according to their shares, which are determined by their reservation payoffs, i.e., the payoffs from the non-cooperative competition, which is equivalent to their bargaining powers as follows:

$s=0.5+\left(\pi_{N}^{0}-\pi_{S}^{0}\right) /\left(2 \pi_{N}^{M}\right)$

Then, profits of firm $\mathrm{N}$ and $\mathrm{S}$ from the joint venture can be expressed as follows reflecting their bargaining powers:

$\pi_{N}^{J}=\left\{\pi_{N}^{M}\left(\underline{e_{S}}\right)+\left(\pi_{N}^{c}\left(\underline{e_{S}}, \mathrm{e}_{\mathrm{S}}\right)-\pi_{S}^{c}\left(\underline{e_{S}}, \mathrm{e}_{\mathrm{S}}\right)\right)\right\} / 2 \equiv \pi_{N}^{J}\left(\underline{e_{S}}, \mathrm{e}_{\mathrm{S}}\right)$
$\pi_{S}^{J}=\left\{\pi_{N}^{M}\left(\underline{e_{S}}\right)-\left(\pi_{N}^{c}\left(\underline{e_{S}}, \mathrm{e}_{\mathrm{S}}\right)-\pi_{S}^{c}\left(\underline{e_{S}}, \mathrm{e}_{\mathrm{S}}\right)\right)\right\} / 2 \equiv \pi_{N}^{J}\left(\underline{e_{S}}, \mathrm{e}_{\mathrm{S}}\right)$

Since the reservation payoffs of firm $\mathrm{N}$ is larger than that of firm $\mathrm{S}$, firm N's share of the JV should be larger than firm S: $1 / 2 \leq s<1$.

Firm S's share is given as $1-S=\frac{\pi_{N}^{M}-\left(\pi_{N}^{0}-\pi_{S}^{0}\right)}{2 \pi_{N}^{M}}>\frac{\pi_{S}^{0}}{\pi_{N}^{M}} \geq 0$, leading to $s<1$. From Eq. (13), $\pi_{N}^{J}-\pi_{N}^{0}=s \pi_{J}-\pi_{N}^{0}=\frac{\pi_{N}^{M}-\left(\pi_{N}^{0}+\pi_{S}^{0}\right)}{2}>0$.

If $s=1$, firm $N$ becomes a monopoly in the market and $\pi_{N}^{M}=\pi_{N}^{0}$ and $\pi_{S}^{0}=0$. This means that there is no possibility for a JV and only firm $\mathrm{N}$ has the whole share of the firm which produces the monopoly outputs. When $\underline{e_{S}} \leq \underline{e^{*}}$, even a monopoly JV makes negative profits, and therefore no firm operates in the market

Proposition 1 (Forming JV). Suppose that $e_{S} \geq e_{N}, \underline{e_{S}}>\underline{e_{N}}$ and $\underline{e_{N}} \leq \underline{e^{*}}$. (i) if $\underline{e_{S}}>\underline{e_{0}}\left(e_{S}\right)$, the JV is formed which produces the monopoly level of output; (ii) if $\underline{e^{*}}<\underline{e_{S}}<\underline{e_{0}}\left(e_{S}\right)$, firm $\mathrm{S}$ exits from the market and firm $\mathrm{N}$ undertakes full-ownership FDI in the South and becomes a monopoly; (iii) if $\underline{e_{S}} \leq \underline{e^{*}}$, neither firm produces. 


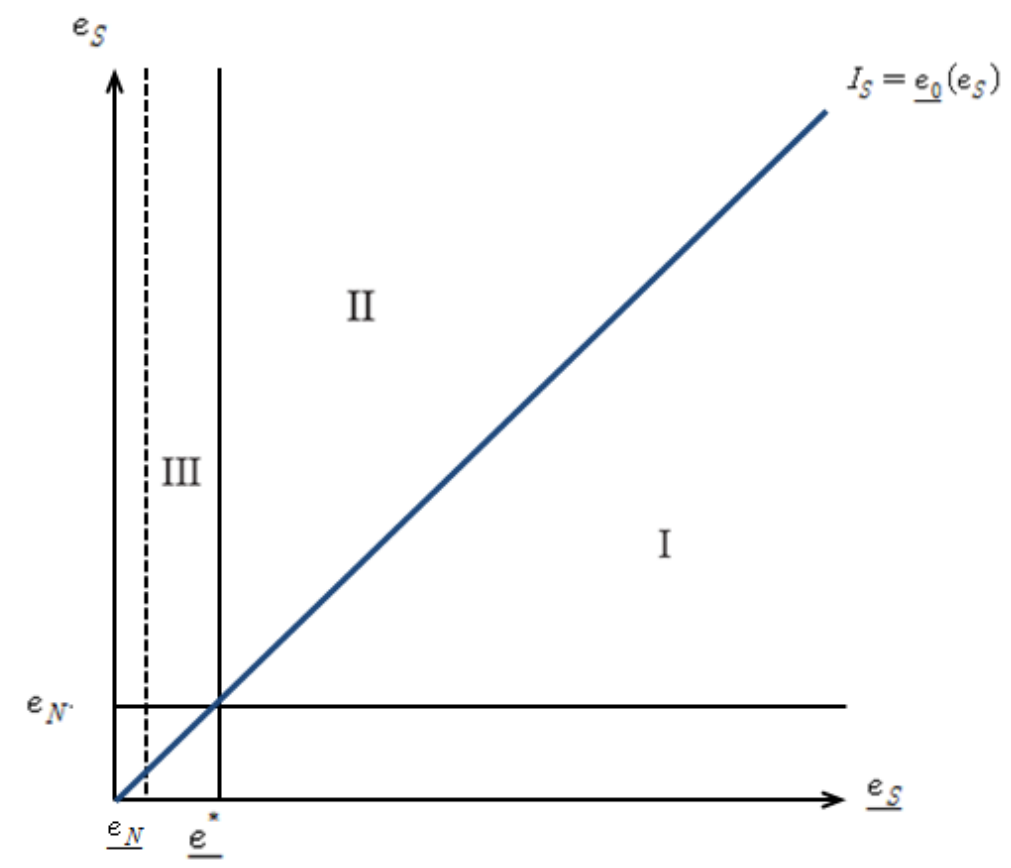

[Figure 5] Formation of JV

Figure 5 illustrates a Case 3 in which both firms are located in the South and a JV is formed. As we observed in figure 5, firm $S$ exists in the market only if $\underline{e_{S}}>\underline{e_{0}}\left(e_{S}\right)$. In addition, neither firm produces anything if $e_{S}<\underline{e}^{*}$. Then, in area I (above $e_{N}$ and to the right of $I_{S}$ ), a JV operates in the South with positive share of firm S. The critical emission standard level for the formation of the $\mathrm{JV}$ is $\underline{e_{S}}=\underline{e_{0}}\left(e_{S}\right)$, which leads to $\mathrm{x}_{\mathrm{S}}^{\mathrm{c}}=0$. In area II (above $I_{S}$ and to the right of $\underline{e^{*}}$ ), full-ownership FDI is formed in the South since firm $\mathrm{S}$ produce zero output and firm $\mathrm{N}$ becomes a monopoly. In area III (to the right of $\underline{e_{N}}$ and to the left of $\underline{e^{*}}$ ), both firms produce nothing.

Proposition 1 indicates that the formation of the JV in the South becomes more difficult as the abatement technology of the South deteriorates. This finding is consistent with the fact that the number of international JVs in least-developed countries (LDCs) is very small, with international JVs much more concentrated in more advanced developing countries such as the Newly Industrialized Countries $(\mathrm{NICs})^{1}$. There is more incentive to determine a higher emission standard to attract JVs when countries have poor abatement technology. Thus, a higher emission standard means an improved bargaining position for firm S in JV negotiations.

1 See Abe and Zhao (2005), and the United Nations Conference on Trade and Development (UNCTAD) (2002, 2011). According to Abe and Zhao (2005), p. 222, 'the 10 largest host countries in the developing world received three-quarters of the total inflows to developing countries, and the 49 LDCs receive only $2 \%$ of them in 2001 ' from the World Investment Report 2002 (UNCTAD).

In addition, according to the World Investment Report 2011 (UNCTAD), p.74-75, LDCs are assured of forming their capital from FDI. However, FDI flows to LDCs are delayed in recovery and the distribution of FDI flows among LDCs still highly uneven as well. FDI is concentrated in a limited number of resource-rich countries and this concentration keeps increasing. The 10 countries with FDI stocks of more than $\$ 5$ billion as of 2010, account for two-thirds of the total inward stock. Between that flow, only four mostly natural resources exporting countriesAngola, Equatorial Buinea, Sudan and Zambia-received over half of the total FDI into LDCs. 


\section{The optimal emission standard for the South}

In figure 2, there is a two-stage game tree, in which the South determines its optimal emission standard level to maximize social welfare, given both the abatement technology and emission standard of the North. We assume that the North decides their emission standard level first, and then the South reacts. There is then no further action in the North. Thus, the South has the advantage of taking action against the other player, the North. It is natural that both parent firms prefer to stay in the South and we already assumed $e_{N}<\underline{e}^{*}$. Therefore, the emission standard level is the only factor which influences whether to form a JV or full-FDI in the South.

In this section, we draw the optimal emission standard level of the South in two cases: (i) full-ownership FDI in the South, and (ii) joint venture in the South.

\subsection{Full-ownership FDI}

Full-ownership FDI exists if firm $\mathrm{N}$ has a 100 per cent of share of the JV. We already examined a case in which firm $S$ produces zero output while firm $\mathrm{N}$ produces positive output, resulting in a monopoly. This is the case when firm $\mathrm{N}$ produces in the South as a monopoly.

For simplicity, suppose that consumer surplus is not calculated within welfare effects since we assume that all output is consumed in a third country. Then, the welfare of the country is composed of the tax revenue and the environmental damage. In this model, we assume that the welfare of the South is the only thing under consideration. Thus, we derive only the South's welfare effects and we do not need to consider the profit of Full-ownership FDI, since it belongs entirely to firm $\mathrm{N}$.

The welfare of the South when a full-ownership FDI is formed in the South is derived as:

$$
\begin{aligned}
W_{S}^{M}\left(\underline{e_{S}}\right)=\left(e_{N}-\underline{e_{S}}\right) x_{N}^{M}-d\left(e_{N}\right) x_{N}^{M} \\
=\frac{\left(\underline{e_{S}}+\beta-e_{N}\right)\left(-\underline{e_{S}}+(1-d) e_{N}\right)}{2 \alpha}
\end{aligned}
$$

This consists of government tax revenue and environmental damage in the South. In Eq. (15), $d$ is the environmental damage per unit of pollution.

It is certain that the South's government chooses an optimal emission standard level to maximize welfare. Then, the optimal emission standard level for the South is: 
$\underline{\mathrm{e}_{\mathrm{S}}^{\mathrm{M}}}=\frac{-\beta+(2-\mathrm{d}) \mathrm{e}_{\mathrm{N}}}{2}$

The welfare of the South with the optimal emission standard level is satisfied:

$W_{S}^{M}\left(\underline{e_{S}^{M}}\right)=\frac{\left(\beta-e_{N} d\right)^{2}}{8 \alpha}$

From Eq. (17), we can examine how other factors affect the welfare of the South.

$$
\begin{aligned}
& \frac{\mathrm{dW}_{\mathrm{S}}^{\mathrm{M}}\left(\mathrm{e}_{\mathrm{S}}^{\mathrm{M}}\right)}{\mathrm{d} e_{N}}=\frac{\mathrm{d}\left(-\beta+\mathrm{de}_{\mathrm{N}}\right)}{4 \alpha} \\
& \frac{\mathrm{dW}_{\mathrm{S}}^{\mathrm{M}}\left(\mathrm{e}_{\mathrm{S}}^{\mathrm{M}}\right)}{\mathrm{d} d}=\frac{\mathrm{e}_{\mathrm{N}}\left(-\beta+\mathrm{de}_{\mathrm{N}}\right)}{4 \alpha}
\end{aligned}
$$

A more clear result could not be obtained algebraically. However, we can find that $\frac{\mathrm{dW}_{\mathrm{S}}^{\mathrm{M}}\left(\mathrm{e}_{\mathrm{S}}^{\mathrm{M}}\right)}{\mathrm{d} e_{N}}<0$, and $\frac{\mathrm{dW}_{\mathrm{S}}^{\mathrm{M}}\left(\mathrm{e}_{\mathrm{S}}^{\mathrm{M}}\right)}{\mathrm{d} d}<0$ assuming that $0<\mathrm{d}<1$.

The welfare of the South under FDI decreases as the R\&D efficiency of FDI through production with firm N's technology worsens as well. Considering environmental damage per unit of pollution, the industry which creates more environmental damage reduces the welfare of the South. The welfare of the South under FDI consists of the tax revenue and the environmental damage. Thus, if pollution damage is serious from FDI, it may offset the tax revenue.

Firm $\mathrm{N}$ makes positive output if $\underline{\mathrm{e}_{\mathrm{S}}^{\mathrm{M}}}>\underline{e^{*}}$. Also firm $\mathrm{N}$ is a monopoly since firm $\mathrm{S}$ makes zero output if $\underline{e^{*}} \leq \underline{\mathrm{e}_{\mathrm{S}}^{\mathrm{M}}}<\underline{e_{0}}\left(e_{s}\right)$. Thus, these optimal emission standards and the welfare of the South are appropriate only if $\underline{e^{*}} \leq \underline{\mathrm{e}_{\mathrm{S}}^{\mathrm{M}}}<\underline{e_{0}}\left(e_{S}\right)$ and $\underline{\mathrm{e}_{\mathrm{S}}^{\mathrm{M}}}>\underline{e^{*}}$ where the Full-ownership FDI has occurred.

\section{$3.2 \quad$ Joint ventures}

A joint venture is formed when both firms $\mathrm{N}$ and $\mathrm{S}$ produce positive outputs. In other words, firm $\mathrm{S}$ under the JV condition has its own share while only firm $\mathrm{N}$ has a share under the full-ownership FDI. Thus, the South's welfare effects from JV differ from those of full-FDI. The South's welfare of JV is:

$$
\begin{aligned}
W_{S}^{J}\left(\underline{e_{S}}, e_{S}\right) & =W_{S}^{M}\left(\underline{e_{S}}\right)+\pi_{S}^{J}\left(\underline{e}_{S}, e_{S}\right) \\
& =\frac{-3\left(3 \underline{e}_{S}-\beta\right)\left(\underline{e_{S}}+\beta\right)+2 \mathrm{e}_{\mathrm{N}}\left\{(13-6 \mathrm{~d}) \underline{e_{S}}+(7-6 \mathrm{~d}) \beta\right\}+(12 \mathrm{~d}-13) e_{N}^{2}+4 e_{S}\left\{e_{S}-2\left(\underline{e_{S}}+\beta\right)\right\}}{24 \alpha}
\end{aligned}
$$

This is composed of the government tax revenue, the environmental damage to the 
South and firm S's profit from the JV. In other words, Eq. (19) $W_{S}^{J}\left(\underline{e_{S}}, e_{S}\right)$ consists of Eq.(17) $W_{S}^{M}\left(\underline{e_{S}}\right)$ and Eq.(14) $\pi_{S}^{J}\left(\underline{e_{S}}, e_{S}\right)$.

Lemma 2 (Joint ventures). (i) $W_{S}^{J}\left(0, e_{S}\right)=W_{S}^{M}(0)+\frac{\pi_{N}^{M}(0)}{2}<W_{S}^{M}\left(\underline{e_{S}^{M}}\right)$, for any $e_{S}$;

(ii) $W_{S}^{J}\left(\underline{e_{0}}\left(e_{s}\right), e_{S}\right)=W_{S}^{M}\left(\underline{e_{0}}\left(e_{s}\right)\right)$, for any $e_{S}$; (iii) $W_{S}^{J}\left(\underline{e_{S}}, e_{S}\right)>W_{S}^{M}\left(\underline{e_{S}}\right)$, for any $\underline{e_{S}} \in\left(0, \underline{e_{0}}\left(e_{s}\right)\right)$

In Lemma 2, first of all, if $\underline{e}_{S}=0$, both firm $\mathrm{N}$ and $\mathrm{S}$ receive the same net profit under the Cournot equilibrium. This means that both firm $\mathrm{N}$ and S's net share becomes 0.5 . Also the welfare of the South under the JV with any $\underline{e_{S}}$ is smaller than the maximum welfare under the full-ownership FDI with an optimal emission standard given by Eq. (17). Secondly, if $\underline{e_{0}}=\underline{e_{0}}\left(e_{s}\right)$, firm $N$ becomes a monopoly which means the net share of firm $\mathrm{N}$ becomes 1 for any $\mathrm{e}_{S}$. Thirdly, the profit of firm $\mathrm{S}$ under the $\mathrm{JV}$ is always positive $\pi_{S}^{J}\left(\underline{e_{S}}, e_{S}\right)>0$, for any $\underline{e_{S}} \in\left(0, \underline{e_{0}}\left(e_{S}\right)\right)$. Thus if the $\mathrm{JV}$ is formed, the welfare of the South is better than that under the full-ownership FDI.

In this case, the optimal emission standard level under JV is derived as Eq. (20). It is derived from differentiating Eq. (19) with respect to $\underline{e_{S}}$ :

$$
\begin{aligned}
\underline{\mathrm{e}_{\mathrm{S}}^{\mathrm{J}}=\frac{\mathrm{d} \mathrm{w}_{\mathrm{S}}^{\mathrm{J}}}{\mathrm{d} \underline{e_{S}}}} & \equiv \underline{\mathrm{e}_{\mathrm{S}}^{\mathrm{J}}}\left(\mathrm{e}_{\mathrm{S}}\right) \\
& =\frac{-3 \beta+(13-6 \mathrm{~d}) e_{N}-4 e_{S}}{9}
\end{aligned}
$$

The welfare of the South with the optimal emission standard level $\mathrm{W}_{S}^{\mathrm{J}}\left(\mathrm{e}_{\underline{S}}^{\mathrm{J}}\left(\mathrm{e}_{\mathrm{S}}\right), \mathrm{e}_{\mathrm{S}}\right)$ is derived from substituting Eq. (20) into Eq. (19). The welfare of the South is that;

$$
W_{S}^{J}\left(\underline{\mathrm{e}_{\mathrm{S}}^{\mathrm{J}}}\left(\mathrm{e}_{\mathrm{S}}\right), e_{S}\right)=\frac{9 \beta^{2}+9 d e_{N}^{2}-6 \mathrm{~d} e_{N}\left(3 \beta+2 e_{N}-2 e_{S}\right)+\left(12 \beta+13 e_{N}-13 e_{S}\right)\left(e_{N}-e_{S}\right)}{54 \alpha}
$$

The optimal emission standard and the corresponding welfare are only valid as long as the JV is sustained. The JV is formed where both parent firms produce positive outputs such as $\underline{e_{N}} \leq \underline{e_{0}}\left(e_{s}\right)<\underline{e_{S}}$ and $\underline{\mathrm{e}_{\mathrm{S}}^{\mathrm{J}}}>\underline{e^{*}}$.

\subsection{The optimal emission standard}

Considering technology transfer, the benefits of full-ownership FDI are about the same as those from the JV. The reason for this is that both full-ownership FDI and the JV use the technology of firm N. In terms of welfare, the JV is obviously a better 
option since a share of the JV's profits is included as a portion of welfare.

However, there are significant differences between the JV and full-ownership FDI in the welfare. First of all, the equilibrium emission standard in case $\underline{e_{0}}\left(e_{s}\right)<\underline{e_{S}}$ where the JV is the unique equilibrium is given as Eq. (20) $e_{S}^{J}$. When social concerns about pollution is higher than the critical value, the optimal environmental regulation is to impose a tougher environmental regulation on firm $\mathrm{N}$ when firm N's emission level is increased even though it is lower than firm $S$ as shown in the follows:

$$
\frac{\mathrm{de}_{\mathrm{S}}^{\mathrm{J}}}{\mathrm{d} e_{N}}=\frac{-6 d+13}{9}<0, \text { if } d_{J V}>\frac{13}{6}
$$

In addition, when the market size is increased, the optimal environmental regulation is getting tougher with a lower maximum allowed emission as follows:

$$
\frac{\mathrm{de}_{\mathrm{S}}^{\mathrm{J}}}{\mathrm{d} \beta}=-\frac{1}{3}<0
$$

Secondly, the equilibrium emission standard in case $\underline{e_{S}}<\underline{e_{0}}\left(e_{s}\right)$ where the fullownership FDI is the unique equilibrium is given as Eq. $(24) \underline{\mathrm{e}_{S}^{\mathrm{M}}}$. In case of monopoly FDI which is the full-ownership FDI, the optimal environmental policy is a tougher regulation in comparison to the case of the JV. The critical value of social concern about the environmental pollution triggering the tougher environmental is lower in case of monopoly FDI as follows:

$$
\frac{\mathrm{de}_{\mathrm{S}}^{\mathrm{M}}}{\mathrm{d} e_{N}}=1-\frac{d}{2}<0 \text {, if } d_{F D I}>2
$$

Therefore, there is relatively lower critical value of social concern about the environmental pollution in the full-ownership FDI than the JV.

$$
\hat{d}_{F D I}=2<\hat{d}_{J V}=\frac{13}{6}
$$

In addition, when the market size increases, the government imposes more strict regulation in case of monopoly FDI than the JV case:

$\frac{\mathrm{de}_{\mathrm{S}}^{\mathrm{M}}}{\mathrm{d} \beta}=-\frac{1}{2}<\frac{\mathrm{de}_{\mathrm{S}}^{\mathrm{J}}}{\mathrm{d} \beta}=-\frac{1}{3}$

The intuition behind the result is that the government has an incentive to be more lenient to JV since the JV provides firm S's share of the JV profits, while monopoly FDI takes the whole producer surplus to the country $\mathrm{N}$. 


\section{Conclusions}

This paper analyzed how environmental regulation affects the FDI strategies of parent firms in the North and the South given their differences in abatement technology. The optimal emission standard level was derived as an environmental regulation of the South under full-ownership FDI and JV conditions. Through modeling which was based on technology differences between the North and the South, it was possible to investigate the different welfare effects for the South depending on the behavior of both parent firms.

This paper examined optimal environmental policies to resolve the policy dilemma between lenient environmental policies to induce FDI inflows and environmental protection of developing economies. We demonstrated that when the emission technology of the developing economy is higher than the critical level, the market dominated by a single joint-venture is the unique equilibrium. We show that if the social concerns about pollution is less sensitive than the critical level, the developing economy provide lenient regulation to induce joint-venture even when the emission of the joint-venture is increased. However, the developing economy takes a tougher regulation when the social concerns and sensitivity about the environmental pollution is higher than the critical level, and the market size of the developing is larger. This paper also demonstrated that the environmental regulation gets stricter when the foreign firm dominates the developing market as a monopoly firm instead of joint-venture after the exit of the inefficient domestic firm.

Environmental issues affect both developing and developed countries. However, developed countries have more incentive to invest in the developing because of CDMs. This study focused on FDI strategies in terms of the welfare of the South, with a view to being able to provide better policy modeling for the developing countries. Environmental regulation is not necessarily a barrier to being competitive; the solution lies in FDI flows involving the transfer of environmentally sound technologies (ESTs).

It is natural that if more lenient regulations exist, it is more attractive to form a JV in the South. However, the southern government will opt for lenient regulation even if the abatement technology of the North, while not good, is still superior to their own. It is certain that the northern firm has better abatement technology than the southern, although the northern firm may not have perfect ESTs. This is a reason for which developing countries impose lenient regulations to attract JVs. Furthermore, the welfare of the developing country is optimal when forming a JV in their country.

This paper has some limitations. First of all, it assumed the demand, emission and damage functions are linear in the model. Adapting this would not be able to change the basic structure of main findings in this paper but it could affect some points. Also the consumer surplus was not considered, since all outputs were assumed to be consumed in the third country. This is different in the real world, thus, 
considering consumers is necessary for future studies.

Secondly, only the welfare of the South was examined. In this model, the South determined their action given the North's strategy. It also should be considered what will come next if there is a chance for the North to react after the South has chosen its response.

Thirdly, the emission standard was considered to be an environmental regulation. However, both firms can reduce emissions through $R \& D$. Thus, it might be possible to execute not only $e_{J-} Z_{J}>\underline{e_{S}}$ but also $e_{J-} Z_{J}<\underline{e_{S}}$ where $Z_{J}$ is the amount of emission reduction through $R \& D$. If firms reduce their emissions in a standardized way, governments may be able to give subsidies to firms so as to encourage them to be more environmentally friendly.

\section{References}

Abe,K., Zhao, L., 2005. Endogenous international joint ventures and the environment. Journal of International Economics 67, 221-240.

Abe,K., Zhao, L., 2000. International joint ventures, economic integration andgovernment policy. In: Ito, T., Krueger, A. (Eds.), The Role of Foreign Direct

Investment in East Asian Economic Development. The University of Chicago Press, Chicago.

Barrett, S., 1994. Strategic environmental policy and international trade. Journal of Public Economics 54, 325-338.

Becker, R., Henderson, V., 2000. Effects of air quality regulations on pollution industries. Journal of Political Economy 108, 379-421.

Celik,S., Orbay, B.Z., 2011. Location choice under trade and environmental policies. Economic Modelling 28, 1710-1715.

Christoph Sutter, Juan Carlos Parreno, 2007. Does the current Clean Development Mechanism(CDM) delier its sustainable development claim? An analysis of officially registered CDM projects. Climatinc Change 84, 75-90.

Copeland, B.R., 1996. Pollution content tariffs, environmental rent shifting, and the control of crossborder pollution. Journal of International Economics 40, 459-476.

European Commission Joint Research Centre \& PBL Netherlands Environmental Assessment Agency, 2012. Trends in global $\mathrm{CO}_{2}$ emissions 2012 report. Internet: http://edgar.jrc.ec.europa.eu/CO2REPORT2012.pdf.

Kennedy, P.W., 1994. Equilibrium pollution taxes in open economies with imperfect competition. Journal of Environmental Economics and Management 27, 49-63.

Kim,Hyun-dong, Whang, Yun-gi, 2010. A study on the problem analysis and improvement plan for environmental tax system-focus on air pollution. Korean Environmental Law Association(環境法 硎究) 32, 237-275

Kristine Farla, Denis de Crombrugghe and Bart Verspagen, 2013. Institutions, Foreign Direct Investment, and Domestic Investment: crowding out or crowding in?, UNU-MERIT Working paper series.

Markusen, J.R., Morey, E.R., Olewiler, N., 1993. Environmental policy when market structure and 
plant locations are endogenous. Journal of Environmental Economics and Management 24, 6986.

Markusen, J.R., Morey, E.R., Olewiler, N., 1995. Competition in regional Environmental policies when plant locations are endogenous. Journal of Public Economics 56, 55-77.

Markusen, J.R., 1997. Costly pollution abatement, competitiveness and plant location decisions. Resource and Energy Economics 19, 299-320.

Petrakis, E., Poyago-Theotoky, J., 2002. R\&D subsidies versus R\&D cooperation in a duopoly with spillovers and pollution. Australian Economic Papers 41, 37-52.

Poyago-Theotoky, J., 2007. The organization of R\&D and environmental policy. Journal of Economic Behavior \& Organization 62, 63-75

Rauscher, M., 1995. Environmental regulation and the location of polluting industries. International Tax and Public Finance 2, 229-244.

Rauscher, M., 1997. International Trade, Factor Movements, and the Environment. Clarendon Press, Oxford.

Sanna-Randaccio Francesca, 2002. The impact of foreign direct investment on home and host countries with endogenous R\&D. Review of International Economics, 10(2), 278-298.

UNCTAD, 2002. The World Investment Report 2002.

UNCTAD, 2011. The World Investment Report 2011.

Ulph, A.M., Valentini, L., 1997. Plant location and strategic environmental policy with inter sectoral linkages. Resource and Energy Economics 19, 363-383. 